\title{
ARTICLES
}

\section{Liberal Democracy and the Judeo-Christian Tradition}

\author{
Tamar de Waal
}

\section{Introduction}

Over the past few decades, politicians and policy documents in Western democracies (broadly defined as Europe, North America, and Australasia) have increasingly begun to state that the universal values underpinning liberal democracy are (historically) connected to the 'Judeo-Christian' tradition of these nations. To name a few examples, the Italian Charter of Values that newcomers are required to sign mentions that 'Christianity (...) together with Judaism has paved the way of acquiring modernity and the principles of freedom and justice. ${ }^{1}$ In the Netherlands, the manifesto of the liberal party VVD (the largest party in the cabinet) states 'Dutch society finds its origins in the Judeo-Christian tradition (...).' Brexit Party politician Nigel Farage regularly states that Britain 'needs to stand up for its Judeo-Christian values'. ${ }^{3}$ In addition, U.S. President Donald Trump said in a speech on October 13, 2017, 'we are stopping cold the attacks on the JudeoChristian values (...).' Often, the term Judeo-Christian is invoked as self-explanatory and consensual, but its precise meaning is almost never articulated.

Academic scholarship shows that the term has a varied history. In the middle of the last century, the term was used in the United States to emphasize the (religious) pluralism and spirit of inclusion that underpinned American democracy, as opposed to Nazism as well as 'godless Communism'. ${ }^{4} \mathrm{~A}$ few decades later, the term became associated with evangelical conservative voices in the United States in the so-called culture wars over abortion and same-sex marriage. ${ }^{5}$ Since the 1990s, the usage of the term has surged worldwide and is now primarily invoked in discussions on the inclusion and integration of Muslims in Western liberaldemocratic states. In this form, the notion of the Judeo-Christian culture was ini-

1 Paolo Cuttitta, 'Mandatory Integration Measures and Differential Inclusion: The Italian Case', Journal of International Migration and Integration 17, no. 1 (2016): 289-302, here 297.

2 Concept-Beginselverklaring VVD 2008, http://pubnpp.eldoc.ub.rug.nl/FILES/root/ beginselprogramma/vvd2008con/con-begverk08.pdf.

3 Kiran Moodley, "Nigel Farage says Britain needs to stand up for its "Judeo-Christian values" to combat homegrown militants', Independent, September 3, 2014.

4 Douglas Hartmann, Xuefeng Zhang, \& William Wischstadt, 'One (Multicultural) Nation Under God? Changing Uses and Meanings of the Term "Judeo-Christian" in the American Media', Journal of Media and Religion 4, no. 4 (2005): 207-34, here 210.

5 Jeffrey Haynes, 'Donald Trump, “Judeo-Christian Values," and the "Clash of Civilizations"', The Review of Faith \& International Affairs 15, no. 3 (2017): 66-75, here 69. 
tially only mentioned by activists, commentators, and politicians positioned on the far right of the political spectrum. More recently, however, it has slowly but steadily begun to influence and establish itself in mainstream political party positions, official political documents, and public stances. ${ }^{6}$

This article explores the legitimacy of this trend from the perspective of liberaldemocratic theory and its functional usefulness. ${ }^{7}$ Indeed, on the one hand, the article interrogates whether it would cohere with liberal-democratic norms if current-day Western democracies would officially adopt a national identity asserting that their values originate in a Judeo-Christian tradition. On the other hand, the article explores more pragmatic concerns surrounding this claim. Would this assertion nurture the social integration, solidarity, and stability that contemporary liberal-democratic countries need to function? To answer these questions, I will first roughly sketch the relationship between liberal democracy and national identities. Subsequently, I will raise the question of whether historical claims must be factually correct to qualify as legitimate national historical narratives of a liberal-democratic country. Then I will focus on how the claim might undermine the value of equal citizenship and equal democratic deliberation between all citizens. Subsequently, I will discuss several practical issues and drawbacks relating to the scrutinized development. Lastly, I will summarize the outcomes of my analyses.

Before proceeding, it is important to clarify two points. First, as I evaluate at face value the normative coherency of the claim that the universal values underpinning liberal democracies are historically linked to the Judeo-Christian tradition of Western states, I will not discuss whether these values are universal or culturally relative. ${ }^{8}$ Put differently, the presented analysis contributes to academic debates on the internal coherence of liberal-democratic theory (in the context of historical national narratives), not on whether liberal-democratic values are or can be universalized at all. In the same vein, I do not engage with political voices - most notably Hungarian Prime Minister Victor Orbán - that argue that liberal values threaten more protection-worthy Christian values. ${ }^{9}$ This concerns a different issue that surely deserves academic attention - namely, that Christianity is (explicitly) used to advocate illiberalism.

Second, this article does not present a full theory on secularism or different strands of secularism, such as offered by Cécile Laborde in her Liberalism's

6 Bart Wallet, 'Zin en onzin van de "joods-christelijke traditie", Christen Democratische Verkenningen 3 (2012): 100-108; M.S. Berger, 'Islam, Europa en de "joods-christelijke beschaving”, Tijdschrift voor Religie, Recht en Beleid 8, no. 2 (2017): 36-56.

7 The article will not provide a detailed and intricate empirical study of political and societal contexts in which the Judeo-Christian culture is mentioned because it focuses on underlying normative and practical concerns.

8 See, e.g., Bhikhu Parekh, 'The Cultural Particularity of Liberal Democracy', Political Studies 40 (1992): 160-75.

9 Krisztina Than \& Sandor Peto, 'Hungarian PM Sees Shift to Illiberal Christian Democracy in 2019 European Vote', Reuters, July 28, 2018. 
Religion. ${ }^{10}$ Rather, it focuses on the underlying normative and practical concerns of statements in favor of liberal democracy and its universal core values, but describe it as historically fastened to a Judeo-Christian tradition. Nonetheless, prima facie, it seems that parts of my analyses are applicable to other related and similar discussions. An example would be discussions on whether human right treaties or EU policy documents should mention a link between Christian, humanist, or European heritages or a Western Leitkultur of fundamental rights. ${ }^{11}$ However, future research is warranted to confirm this.

\section{Liberal democracy and national identity}

An important part of the answer to the question of whether it is normatively legitimate for states to frame (Western) liberal democracy as the product of a Judeo-Christian heritage or culture can be found in the longstanding debate in political philosophy on what the social preconditions of liberal freedom and equality are. Most academic commentators broadly agree that political communities including liberal ones presuppose what David Miller calls 'ethical communities' $^{12}$ and, therefore, have a legitimate interest in nurturing and upholding these. Indeed, political theorists generally agree that liberal justice requires a sense that citizens belong together in a country, feel solidarity with each other, and govern themselves collectively. ${ }^{13}$ However, this begs the following question: what can and should be the basis for such a shared sense of communal belonging?

Both theoretically and practically, it is widely regarded as permissible and promising for states to build solidarity by appealing to ideals of nationhood. Today, virtually all liberal-democratic states deploy nation-building tools, such as compulsory education, national media, official language laws, naturalization rituals, and national holidays and symbols. In academic debates, this is called a 'liberal nationalist' approach to social unity. ${ }^{14}$ The objective of this approach is to consolidate a feeling among citizens that they belong to an ethical community of people who share an intergenerational society with a territory, shared institutions, history, and future. More specifically, academic advocates of liberal nationalism argue that states are permitted to foster forms of nationhood in order to secure solidar-

10 Cécile Laborde, Liberalism's Religion (Cambridge, MA: Harvard University Press, 2017).

11 See, e.g., Joseph Weiler, Un'Europa cristiana: un saggio esplorativo (Milan; Bureau, 2003); Agustín José Menéndez, 'A Christian or a Laïc Europe? Christian Values and European Identity', Ratio Juris 18, no. 2 (2005): 179-205.

12 David Miller, On Nationality (Oxford: Clarendon Press, 1995). See also Christian Joppke, 'A Christian Identity for the Liberal State?', The British Journal of Sociology 64, no. 4 (2013): 597-616; Roland Pierik, 'State Neutrality and the Limits of Religious Symbolism', in The Lautsi Papers: Multidisciplinary Reflections on Religious Symbols in the Public School Classroom, vol. II, Studies in Religion, Secular Beliefs and Human Rights, ed. Jeroen Temperman (Leiden: Brill/Nijhoff, 2012).

13 See also, e.g., Yael Tamir, Why Nationalism (Princeton, NJ: Princeton University Press, 2019).

14 Will Kymlicka, Contemporary Political Philosophy: An Introduction (Oxford: Oxford University Press, 2002), 264. 
ity and stability as long as the national identity is 'thin' and underpinned by the principles of liberal democracy (e.g., individual and constitutional norms, tolerance, and equality). This thinness entails that the state may promote national languages, public holidays, and the like, but that the national identity promoted simultaneously remains inclusive of people from different backgrounds (ethnic, cultural, religious, etc.) and does not limit the capacity of individual citizens to choose or revise their personal conceptions of what a meaningful life is. ${ }^{15}$ On a more fundamental level, liberal nationalists assert that the norms and skills of democratic citizenship are not innate but must be learned, socialized, and practiced. Therefore, the state is permitted to create an ethical community with an official language, symbols, and common institutions. Under these circumstances, it is thought that people are most likely to fulfill their obligation of promoting justice toward each other and be able to participate as equals in democratic deliberation and societal life. ${ }^{16}$ Hence, liberal nationalists not only see liberalism and images of the nation as reconcilable but as complementary and capable of strengthening each other. Or as Yael Tamir writes, 'No individual can be context free, but... all can be free within a context.' ${ }^{, 17}$

From this perspective, it becomes clear that the inner logic of liberal democracy indicates that if a state fosters its national identity and values as outright JudeoChristian, this is exclusionary toward citizens with different religious or non-religious backgrounds, who then (discursively) cannot belong to the nation or have access to the core values of the state. Indeed, if invoked this way, Judeo-Christian is a term 'defined by exclusion', implying the direct rejection of both secular citizens and those of different faiths. ${ }^{18}$ This jeopardizes liberal democracy because this political regime is distinguishable from illiberal or undemocratic states precisely by not promoting the national identity and connected conceptions of citizenship as exclusively based on a particular religious orientation (or cultural background, ethnic descent, political outlook, etc.). The current increase in politicians in power and policy documents suggesting that present-day Western democracies and their values are (still) Judeo-Christian can, therefore, be qualified as signs of illiberal tendencies that Triadafilos Triadafilopoulos coined as 'Schmittian liberalism'. ${ }^{19}$ This entails the suggestion that the exclusion of (putatively) illiberal and dangerous groups (most often Muslims) is deemed a requirement to protect

Kymlicka, Contemporary Political Philosophy, 265.

An open question for liberal nationalists remains why the nation-state would be the best (or perhaps even only) political unit and social context to achieve such an 'ethical community'. For a more cosmopolitan critique of liberal nationalism, see, e.g., Dora Kostakopoulou, The Future Governance of Citizenship (Cambridge: Cambridge University Press, 2008).

Yael Tamir, Liberal Nationalism (Princeton, NJ: Princeton University Press, 1995), 4. Haynes, 'Donald Trump', 69.

An example would be that the Dutch anti-Muslim party, PVV (Party of Freedom), proposed to reject the first article of the Dutch constitution - which contains the principle of equality and proscription of discrimination - with a reference stating that Dutch society is based on the Judeo-Christian tradition. PVV, 2010, https:/pvv.nl/index.php/component/content/ article.html?id=5516. 
the universal values of the West that, paradoxically, requires cultural homogeneity. ${ }^{20}$

However, it must be observed that most policy documents or statements by (mainstream) politicians in power do not stress that the liberal-democratic state today is exclusively for Jewish and Christian citizens. Instead, they emphasize that the Judeo-Christian tradition of Europe is the historic seedbed of present-day liberal-democratic values. Such statements raise the question: what are the normative guidelines for liberal-democratic states to make such historical statements about the national identity? This question touches on scarcely explored territory within political and legal theory. Yet if the state is indeed permitted to foster a national identity - as liberal nationalists claim - this evidently includes promoting at least a few historical reference points to foster sense of belonging to a society with a common past and a shared common future. Then, how should a liberaldemocratic state determine what these historical reference points are, and who gets to decide?

\section{National historical narratives: true story?}

The first pertinent question in this context appears to be: must the state-promoted national historical narrative be true? This is relevant for evaluations of the claim that the Judeo-Christian history of Western democracies is the historical context of the birth of liberal-democratic norms because a much heard, and at first glance reasonable, critique of it is that it is simply untrue. Most academic studies on the term strongly reject it and conclude that the Judeo-Christian tradition is, above all, a retrospectively 'invented tradition'. ${ }^{21}$ Among other things, scholars argue that the term problematically conflates the story of Christianity with that of the Jewish people in the West, concealing the centuries-long antiSemitic prosecution of Jews by Christians throughout Western history and even camouflaging the memory of the Holocaust. ${ }^{22}$ Indeed, the academic communis opinio appears to be that to describe the history of Western liberal democracies as Judeo-Christian is not only false but also cynical, because it whitewashes the blackest pages of Western history. ${ }^{23}$ Additionally, it is often critically observed that the Judeo-Christian history of Western democracies is frequently invoked to stress that women's and gay rights have been protected 'for centuries' in these

20 Triadafilos Triadafilopoulos, 'Illiberal Means to Liberal Ends? Understanding Recent Immigrant Integration Policies in Europe', Journal of Ethnic and Migration Studies 37, no. 6 (2011): 861-80, here 867.

21 See, e.g., Ernst van den Hemel, “Hoezo christelijke waarden?” Postseculier nationalisme en uitdagingen voor beleid en overheid', Tijdschrift voor Religie, Recht en Beleid 8, no. 2 (2017): 5-23; Anya Topolski, 'A Genealogy of the "Judeo-Christian" Signifier: A Tale of Europe's Identity Crisis', in Is There a Judeo-Christian Tradition?: A European Perspective, eds. Emmanuel Nathan \& Anya Topolski (Berlin: De Gruyter Mouton, 2016), 221-66.

22 See, e.g., Hartwig Pautz, 'The Politics of Identity in Germany: The Leitkultur Debate', Race \& Class 46, no. 4 (2005): 39-52.

23 Berger, 'Islam, Europa', 46. 
countries (in contrast to in the Muslim world), while this is a form of historical negationism because their commitment to (equally) protecting these rights is a relatively recent phenomenon. ${ }^{24}$ Lastly, the historical relationship between Christianity and contemporary liberal values is contested and a subject of long-standing debate. ${ }^{25}$ For example, Robert I. Moore argues that ideas of human rights have emerged in Europe rather despite than due to Christianity - a religion that is historically responsible for fueling wars, legitimizing slavery, punishing heresy, and violently censoring scientists and philosophers. ${ }^{26}$ However, in response, other historians, such as Larry Siedentop, have argued that individualism, equality, and liberalism are products of Christianity. ${ }^{27}$

Yet prior to resolving this matter, one can question how normatively relevant the truthfulness of official national historical narratives is. For instance, in his famous 1882 lecture 'Qu'est ce qu'une nation?' Ernest Renan claimed that national identities always depend on selective and even distorted memories of events. Indeed, Renan argued that the nation is always constituted by two things: shared past memories and the present will to live together. The latter he described as the normative requirement for the legitimacy of the state, while he saw the former as the affective source that empirically motivates people to participate in an ethical community (avant la lettre). ${ }^{28}$ Interestingly, he reasoned that careful historical studies can pose a threat to the capacity of a national identity to keep a society together. According to Renan, forgetting, and even historical errors, 'are an essential factor in the creation of the nation, and so it is that progress in historical studies is often a danger to nationality'. ${ }^{29}$ Renan does not stand alone in this. Other commentators, such as Benedict Anderson, have also famously written that states are 'imagined communities'. ${ }^{30}$ Additionally, Miller asserts, '[n] ational identities typically contain a considerable element of myth' and, therefore, 'it may not be rational to discard beliefs, even if they are, strictly speaking false, when they can be shown to contribute significantly to the support of valuable social relations'. ${ }^{31}$ This line of reasoning suggests that creating a historical narrative that is not (fully) true - for instance, one that is based on a Judeo-Christian culture that never really existed - is not per se problematic because its purpose is not to be true but to further social integration and stability. Put differently, from this perspective, if a national identity is appealing and strengthens forms of solid-

29 Renan, 'Qu'est-ce qu'une nation?', 891.

30 Benedict Anderson, Imagined Communities: Reflections on the Origins and Spread of Nationalism (London: New Left Books, 1983).

31 Miller, On Nationality, 34-35. 
arity and spirituality, which a liberal democracy requires to function, there might be no direct normative problem.

Nonetheless, this argumentation leads to a new set of issues. For example, from the perspective of liberal democracy, all citizens should be able to contest the character of the national historical narratives that are promoted by the state. Thus, if, say, the stories of aboriginal groups in Canada or Australia were to be ignored in the official national self-images of these countries, the liberal-democratic core of these states would make it possible for citizens to contest such a national historical self-image. In the same vein, the current debate in the Netherlands on whether the 17th century should still be described as 'the Dutch Golden Age' - which is said to problematically reject the dark sides of colonialism and slavery - is in principle legitimate. ${ }^{32}$ Irrespective of the outcomes of such debates, in a liberal democracy, all citizens should be invited to contribute to constant dialogues on how the national history should be depicted.

However, if we accept that national narratives are not, and do not need to be, genuinely historically true, citizens, then, cannot criticize the national historical narratives on the basis of their truthfulness. Indeed, a strange situation arises if we accept that promoted historical narratives contain myths and do not need to be (fully) true. Liberal-democratic states must reply to citizens who contest the official version of the national narrative with paternalistic lies ('but it is true!' while knowing better) or admit that it is indeed not much more than a fixed but helpful story of the nation, which has little do to with truth, but has been chosen by the state to create a sense of community. ${ }^{33}$ As I see it, both options are selfdefeating for a liberal democracy, where democratic deliberation must be open to contest certain power structures. This implies that citizens deserve respect (i.e., not being lied to by the state) and should have equal opportunity to discuss and challenge the dominant historical national narratives. In other words, it cannot be demanded of liberal-democratic citizens to take the official national historical narratives for granted. This is important because differences in positions of sociopolitical power that stem from historical narratives - for example between those who emphasize that contemporary Europe owes its values to Judeo-Christian influences rather than to Enlightenment thinkers (as argued by Jonathan Israel $^{34}$ ) or Islamic-Christian influences (as argued by Richard Bulliet ${ }^{35}$ ) - are significant. For this reason, the national identity must always be subject to democratic scrutiny.

32 'Amsterdam museum ditches "Golden Age" in favour of inclusive "17th century", Dutchnews.nl, September 13, 2019, https://www.dutchnews.nl/news/2019/09/amsterdam-museum-ditchesgolden-age-in-favour-of-inclusive-17th-century/.

33 Arash Abizadeh, 'Historical Truth, National Myths and Liberal Democracy: On the Coherence of Liberal Nationalism', The Journal of Political Philosophy 12, no. 3 (2004): 291-313, here 299.

34 Jonathan Irvine Israel, Radical Enlightenment: Philosophy and the Making of Modernity, 1650-1750 (Oxford: Oxford University Press, 2001).

35 Richard W. Bulliet, The Case for Islamo-Christian Civilization (New York/Chichester: Columbia University Press, 2006). 
Based on this line of analysis, Arash Abizadeh reasons that it is indeed not coherent with liberal-democratic norms if truth cannot be a basis for critique of statepromoted national historical narratives. He writes, '[t]aking certain myths for granted (...) is incompatible with the liberal-democratic commitment to the critique of power. ${ }^{36}$ For this reason, he concludes that the argumentation of Renan, Anderson, and Miller is either incorrect or incomplete. Abizadeh's full analysis is multi-layered. For instance, he makes distinctions between the different types of myths that a state can promote and analyzes their different normative implications. However, for the purposes of this article, what is most relevant is his convincing demonstration that liberal-democratic norms require that national historical narratives should be perpetually subjected to political contestation and should be criticized on the basis of (1) truth/falsity and (2) significance. ${ }^{37}$

To begin with the first criterion, Abizadeh explains that liberal-democratic principles require that critical discourses about the truth or falsity of national historical narratives must occur because, otherwise, forms of state power are not governed by democratic deliberative processes. These debates about the truth or falsity of promoted national historical narratives will always continue - presumably with historians, but other citizens as well, playing an important role - because all historical narratives omit true statements about the past. ${ }^{38}$ These debates can be the result of a lack of historical data or because new data have become available. However, the continuous nature of these debates is inevitable because it is simply impossible to sum up all true historical facts as the official national historical narrative: one must add interpretation, a storyline, and emphasis on what should be viewed as historically most important. On that account, Abizadeh states that debates about historical truths have a 'semi-autonomous logic of their own'. 39 This means that debates on the truthfulness of nations' historical narratives take place independently of both what these states want these narratives to be and what would be the most useful narrative for these nations.

In relation to his second criterion, Abizadeh explains that this touches on more normative and ethical questions about what is significant to the nation and what its interests are. In other words, in a liberal-democratic state, part of the debate on the national historical narrative should focus on whether the promoted national narrative is 'appropriate' as the identity-grounding narrative of a liberaldemocratic country. What does the societal 'we' want its big story to be? To be sure, considering Abizadeh's first criterion, this does not mean that (parts of) the national historical story can be (partly) untrue. However, it does require the selection of historical facts fostered by the state as the national historical narrative should promote ethical lessons that are justifiable according to what people deem important for their liberal-democratic state. Also in this context, all citizens

Abizadeh, 'Historical Truth', 302.

Abizadeh, 'Historical Truth', 309.

See also Arthur C. Danto, 'Narration and Knowledge', Philosophy and Literature 6, no. 1 (1982): 17-32.

Abizadeh, 'Historical Truth', 310. 
should have an equal voice in what is significant to them, as this is necessary for the liberal-democratic justification of the exercise of power that the promotion of a particular historical narrative entails.

I will return to this significance criterion in relation to the Judeo-Christian tradition in section 3 , but only after addressing the main question of this section pertaining to whether, from the perspective of liberal democracy, historical narratives are required to be truthful. The answer to this question is that Renan, Anderson, and Miller (among others) are right that upholding a particular national historical narrative necessitates 'forgetting' or, rather, omitting certain true historical facts. Indeed, given that, on the one hand, promoting all historical facts is practically not possible and, on the other hand, national historical narratives ideally should be both true and appropriate, this unavoidably leads to the effect that certain historical facts will not be part of these narratives. However, this is not the case because the state's historical narrative is a myth for which the criterion of truth is not relevant. Rather, from the perspective of liberal democracy, the aspiration should be that historical narratives are, first of all, true. Subsequently, the final selection of true facts that together form the national historical narrative should be legitimized and based on their ethical significance for the identitygrounding historical narrative of a liberal-democratic state. ${ }^{40}$

On that account, if we return to the question of whether promoted historical narratives need to be true, it must be concluded that this is, in fact, of (vital) importance, even though Renan, Anderson, and Miller seem to conclude otherwise. Furthermore, given that the academic communis opinio is that historical evidence for the claim that Western democratic values originate in a Judeo-Christian tradition is relatively weak, it is likely - although the debate on matters such as this will and should always continue - that there are 'better' (in the sense of truer) historical national narratives available for current-day liberal-democratic nations.

\section{The Judeo-Christian identity and equal citizenship}

To briefly take stock, so far, I have established that liberal-democratic theory indicates that a national identity is permissible as long as it is 'thin' and inclusive of all citizens. This implies that a liberal-democratic state should preclude presenting its present-day national identity and core values as exclusively or inherently Judeo-Christian. In addition, I have explained that state-endorsed national historical narratives should be true and appropriate and, based on these criteria, subjected to ongoing democratic deliberation. Further, from this perspective, the available historical scholarship suggests that there is relatively little evidence to support the historical interpretation that democracy and human rights are products of a Judeo-Christian history of Europe. 
In this section, I will further scrutinize the appropriateness of state-endorsed statements indicating that the values of Western liberal democracies are historic products of the Judeo-Christian tradition of the West. In particular, I will focus on the normative issue that such official national historical narratives carry the risk of reinforcing social hierarchical differences between, in this case, citizens with and without Jewish and/or Christian backgrounds in their status as equal citizens. This would make this historical narrative unfit to become the big historical story of liberal-democratic states, as these states have a special responsibility to promote equal citizenship to legitimately govern a people in a territory. ${ }^{41}$

To demonstrate this, it is important to highlight that if the universal liberal-democratic core norms are claimed to derive from the Judeo-Christian history of the West, it is often implied that these values are directly and fully intertwined with this specific history. On that account, the claim carries the risk of suggesting, as Christian F. Rostbøll puts it, that 'there is only one true way of understanding and accepting liberal principles', ${ }^{42}$ and that is through the exact same historical path that (allegedly) originally Judeo-Christian societies have taken. Relevant to this argument are the timing and context in which 'new' historical narratives are introduced. As mentioned in the introduction, the rise of statements that a Judeo-Christian belief system has been crucial for the development of liberaldemocratic values has taken place against the background of discussions on Muslim integration in Western democracies. In particular, within these debates, an image is frequently sketched in which 'natives' and citizens with immigrant backgrounds from (historically, predominantly Christian) Western countries are assumed to be culturally, morally, and psychologically formed by the Judeo-Christian historical tradition such that they are able to understand and embrace liberal-democratic universal values. Thus, within this image, even atheists are seen as belonging to this group; despite their lack of faith today, they are implicitly or explicitly seen as subconsciously formed by a Judeo-Christian tradition (and are at times described as 'culturally Christian'). ${ }^{43}$

At the same time, Muslim citizens and immigrants are implicitly or explicitly problematized because they are singled out as being culturally, psychologically, and morally formed by (religious) histories that suffer from value-based incompatibility with 'the West'. ${ }^{44}$ To be sure, Muslims are portrayed, in principle, as capable of

41 See, e.g., Carina Fourie, Fabian Schuppert, \& Ivo Wallimann-Helmer, Social Equality: On What It Means to Be Equals (Oxford: Oxford University Press, 2015); Nancy Fraser, 'Recognition without Ethics?', Theory, Culture \& Society 18, nos. 2-3 (2001): 21-42; Elizabeth S. Anderson, 'What Is the Point of Equality?', Ethics 109, no. 2 (1999): 287-337.

42 Christian F. Rostbøll, "The Use and Abuse of "Universal Values" in the Danish Cartoon Controversy', European Political Science Review 2, no. 3 (2010): 401-22, here 406.

43 In the Netherlands, for instance, politicians Frits Bolkestein, Pim Fortuyn, and Thierry Baudet argued this about atheists. However, it must be noted that within this cultural-religious historical framework, it remains unclear what the positions of certain groups are, such as atheists who are former Muslims and Christians from African or Asian backgrounds. Are they members of the Judeo-Christian tradition? See also Van den Hemel, “'Hoezo christelijke waarden?", 15-18. 
supporting liberal-democratic core norms, but only if they undergo the exact same transition that initially Judeo-Christian cultures underwent in the past (i.e., a Muslim Enlightenment that reproduces the European Age of Enlightenment). In this context, for instance, Per Mouritsen describes how Denmark presents itself to Muslim immigrants as having a 'particular universalism', in which an intrinsic relationship is suggested between the 'Lutheran Danish identity' and the values of democracy, liberal tolerance, and redistribution. For this reason, Muslims in Denmark are seen as able to support the liberal-democratic values of the state only via the privatization of their religion as exemplified by Luther. ${ }^{45}$

Understanding that this approach jeopardizes the value of equal citizenship is significant because several academic commentators have argued that if 'nationally anonymous' universal values are propagated in liberal-democratic states, such as freedom, the rule of law, tolerance, and so forth, this cannot be exclusionary. ${ }^{46}$ However, this analysis shows that referring to universal values in fact can be exclusionary if one fails to distinguish the history of a certain (majority) culture in relation to these values from the more abstract ideas. On that account, if a state officially promotes the core universal norms that underpin it as (exclusive) products of the history of the cultural majority - especially if it does so as a direct response to public tensions regarding matters of immigration and diversity - it risks fueling a social hierarchy in which citizens with minority backgrounds are marginalized, rather than seen as equal partners, in democratic deliberations. In particular, it signals that, at the end of the day, citizens who belong to the (in this case, traditionally Judeo-Christian) majority are, for historical reasons, better equipped than other citizens to determine the meaning of universal values. More precisely, if liberal-democratic states invoke their Judeo-Christian cultural heritage in this way, this frame is susceptible to insinuating that there is a binary social opposition between a homogeneous culturally Judeo-Christian (native) 'us' and a homogeneous culturally (foreign) non-Judeo-Christian 'them'. This further implies that the former group has historical access to the correct interpretation of universal values - a privilege that non-Judeo-Christian citizens in principle (still) lack. $^{47}$

Of course, this binary opposition distorts a far more complex reality. For instance, it suggests that the historically Judeo-Christian cultural majority fully embodies and supports these universal values, whereas this is virtually always not

45 Per Mouritsen, 'The Particular Universalism of a Nordic Civic Nation', Multiculturalism, Muslims and Citizenship: A European Approach, eds. Tariq Modood, Anna Triandafyllidou, \& Ricard ZapataBarrero (London: Routledge, 2006), 76.

46 See, e.g., Christian Joppke, 'Immigration and the Identity of Citizenship: The Paradox of Universalism', Citizenship Studies 12, no. 6 (2008): 533-46; Liav Orgad, "Cultural Defence" of Nations: Cultural Citizenship in France, Germany and the Netherlands', European Law Journal 15, no. 6 (2009): 719-37.

47 See also Tamar de Waal, 'Conditional Belonging: Evaluating Integration Requirements from a Social Equality Perspective', Journal of Intercultural Studies, forthcoming. 
fully true. ${ }^{48}$ Moreover, the value of equal citizenship requires that if citizens contribute to deliberative democratic processes used to interpret, refine and revise the core norms of the state, they should not be marginalized in their status as equal citizens. This means that all citizens should be taken seriously as being able to discuss universal rights (also if they hold completely different, perhaps religious, views on the meaning of certain core values than the cultural majority). Therefore, the liberal-democratic state should emphasize that all citizens are equally invited, equipped, and entitled to participate as interpreters of the values that underpin the state. They may equally point out where they believe their implementation can be improved, irrespective of the cultural or religious historical background of the group to which they (are perceived to) belong. Therefore, any identity-grounding historical narrative of a liberal-democratic state should insist this, as Abizadeh puts it, be appropriate for its function.

Undeniably, this line of analysis acknowledges that the realization and protection of universal values in specific liberal-democratic countries is a precarious and praiseworthy achievement. Moreover, it acknowledges that this realization is historically situated and culturally contingent - and that in several Western democracies, these values are relatively well secured. Lastly, it does not reject that it is a matter of public concern if citizens outright reject liberal-democratic core norms. For all these reasons, present-day liberal-democratic countries have a legitimate interest in defending their basic principles and values and have every right to deem it as invaluable to, for instance, teach them to both born citizens and newcomers. In this education, references to certain religious or spiritual histories can even be seen as valuable. However, the crux is that if one truly believes in the normative validity of universal rights, the fact that a particular country, culture, or part of the world currently manages to protect them relatively well does not prove that it is impossible for people from other countries, cultures, or parts of the world to equally adopt them through their own historical heritages and traditions. Quite the contrary, if one truly believes that certain values are universal, one must defend that, in principle, all routes can lead to Rome, so to speak, and one can come to understand and accept these values via different (historical, religious, cultural, etc.) paths. Conversely, if one argues that universal values cannot be separated from certain religious or cultural histories - and all groups must adopt exactly the same path that other groups have taken to be able to support these values - the claim to universalism must be abandoned. ${ }^{49}$ The challenge, therefore, is to identify ways to publicly talk, encourage, and promote liberaldemocratic values and uphold a specific ethical community based on these while simultaneously explaining that the connection between these values and the specific religious-cultural history of that community does not make these values inseparable from any specific culture or cultural history. Only in this way can universal values be invoked in an inclusive manner.

48 A case in point would be the current rise of nativist populism in Western democracies. See, e.g., Yascha Mounk, The People vs. Democracy: Why Our Freedom Is in Danger and How to Save It (Cambridge, MA: Harvard University Press, 2018). 


\section{Sharing liberal democracy: some practical concerns}

In the previous sections, I established from the (normative) perspective of liberaldemocratic theory that if Western liberal democracies would adopt the official national narrative that their universal values are historically linked to their Judeo-Christian heritage, this would lead to tensions with liberal-democratic norms. In this section, I will raise a few more pragmatic concerns that I think would arise if this were indeed to become the official historical narrative of Western democracies.

First, the liberal-democratic state should devise strategies to ensure that its core values remain attractive for future generations and strive to successfully encourage and socialize all citizens to support them. For this reason, emphasizing that the origins of liberal democracy and human rights are Judeo-Christian might not be the most pragmatic way forward. This presentation of these values may render it virtually impossible, or at least very difficult, for citizens from non-JudeoChristian backgrounds to support them without entirely disconnecting themselves from their religious history and heritage. Indeed, if the cultural majorities of Western democracies promote their values as 'historically ours', this may prevent these values from providing a solid foundation for a society that operates on the basis of equality. This might demotivate persons from different backgrounds to feel genuinely invited to participate in liberal-democratic debate while the cultural majority simultaneously will also be less inclined to perceive them as such. ${ }^{50}$ All of this is unfortunate because notions of universal values and fundamental rights seemingly do have the potency to function as fertile common ground for cultivating a political community based on peaceful co-existence. Thus, if the universal aspirations of liberal democracies are supported, the state should promote these values as, in principle, transcending particular histories and cultural traditions and as equally accessible to all citizens in order to foster equal belonging and democratic attitudes. In the academic literature, the concept of 'constitutional patriotism' developed by Jürgen Habermas would be a possible version of this ideal leaning on a very thin conceptualization of national identity. ${ }^{51}$ However, forms of 'multicultural nationalism', such as proposed by Tariq Modood would also fit this ideal, entailing a considerable 'thickening' (as opposed to thinning) of the national identity by constantly striving to include traditions, cultures, and heritages of all (immigrant/non-immigrant) citizens in it. ${ }^{52}$

Second, the claim that the universal values of liberal democracy are the result of the West's Judeo-Christian history may quickly lead to the public perception that certain forms of diversity (e.g., involving Muslims) are a challenge as such to the

50 Kwame Anthony Appiah, The Lies That Bind: Rethinking Identity (London: Profile Books, 2018), chap. 6.

51 See, e.g., Jan-Werner Müller, Constitutional Patriotism (Princeton, NJ: Princeton University Press, 2009).

52 Tarid Modood, 'A Multicultural Nationalism?', Brown Journal of World Affairs 25, no. 2 (2019): 233-46. 
preservation of the liberal-democratic state. Indeed, if a state strives to uphold universal liberal-democratic values, one would expect this to lead to the promotion of negotiation, tolerance, reciprocity, and a willingness to accommodate groups in a liberal fashion. Yet this is not necessarily the case if these values are increasingly seen as tribalistic notions that should be culturally protected against groups of citizens with different heritages. Triadafilopoulos writes that such 'aggressive liberalism is likely to deepen rifts between groups, intensifying ill-will and cutting off possibilities for dialogue', because conducting 'polite conversation' with citizens from historically non-Judeo-Christian backgrounds 'would be a grave mistake' because they pose a cultural threat to liberal democracy. ${ }^{53}$ Consequently, this particular historical self-image of liberal-democratic states might, instead of fostering social unity, in fact exacerbate the problems that it should aim to resolve, such as the unequal sense of belonging among citizens and social tensions between groups.

Third and lastly, the idea behind liberal democracy is that it works best if it succeeds in upholding inclusive communication to ensure that all citizens' basic interests are met. ${ }^{54}$ Accordingly, the state should promote inclusive democratic debate because its practical capacities for protection and problem-solving depend on ongoing debate and unwavering commitment. Therefore, democratic states should emphasize that the meaning and interpretation of their core norms are not set in stone but, rather, are constantly up for debate. More precisely, as liberal democracy rests on the conviction that it is always possible for citizens, if they carefully listen to each other's perspectives, to acquire a better understanding of what these universal values are, they should adopt the required attitudes to achieve this end. For this reason, liberal-democratic states should nurture a form of 'reasonableness', defined by Iris Marion Young as, at least, a willingness to listen to others, even if citizens deem each other's ideas incorrect or outright repulsive. ${ }^{55}$ Surely, this reasonableness will not ensure that citizens will always be able to convince each other and reach a consensus. Political disagreement will never disappear. However, when it comes to the protection of universal values and human rights, Martha Nussbaum duly writes that all countries will always remain developing countries. ${ }^{56}$ This implies, among other things, that the state should accentuate that no group of citizens ever perpetually owns universal values, for historic reasons or otherwise. Or as Kwame Anthony Appiah puts it, supporting a culture of liberty and tolerance is not a 'birthright' but is determined by who actually cares about it. ${ }^{57}$ On that account, all citizens should, in principle, be able to speak freely in political discussions, without being marginalized owing to their cultural or religious identity, to be able to solve collective problems and promote justice.

Triadafilopoulos, 'Illiberal Means to Liberal Ends?', 864-72. Iris Marion Young, Inclusion and Democracy (Oxford: Oxford University Press, 2002). Young, Inclusion and Democracy, 25.

Martha C. Nussbaum, Creating Capabilities (Cambridge, MA: Harvard University Press, 2011), preface.

Appiah, Lies That Bind, 211. 


\section{Conclusion}

In this article, I explored from the perspective of liberal-democratic theory the legitimacy of the trend in Western democracies whereby the universal values that underpin the state are increasingly described as historically linked to a JudeoChristian heritage. In addition, I briefly examined various more pragmatic challenges that I believe would arise if this national historical narrative and self-image would be adopted.

My findings are critical for several reasons. First, I established that if a democratic state promotes its current national identity as exclusively Judeo-Christian, this would exclude citizens from other or no religious background from truly belonging to the nation. Second, I reasoned, primarily drawing on the work of Abizadeh, that the historical national narratives of liberal-democratic states should be criticized according to the criteria of truthfulness and appropriateness, and that the historical narrative scrutinized in this article, on the surface, seems to fail to meet either criterion (but debate on these matters will always continue). Third, I reasoned that if the national historical narratives of liberal democracies emphasize that their values stem from a Judeo-Christian heritage, this would carry the risk of damaging the value of equal citizenship. That is, it could inculcate the perception that citizens from non-Judeo-Christian backgrounds are perceived as less equipped to interpret liberal-democratic core norms. Lastly, I determined more pragmatically that this historical narrative might alienate groups, hamper feelings of belonging, and prevent inclusive political communication. It is not likely to facilitate the best conditions under which all citizens can be(come) committed to nurturing a shared society and recognizing each other as equally belonging to it. 